\title{
Ischaemic heart disease mortality among men in Norway: reversal of urban-rural difference between 1966 and 1989
}

\author{
Øystein Krüger, Asbjørn Aase, Steinar Westin
}

\begin{abstract}
Objective - This study aimed to examine regional urban-rural differences in mortality from ischaemic heart disease, including sudden death of unknown cause (IHD/SUD) in Norway from 1966-89, for men and women aged $30-69$ years.

Design - Analysis was based on vital statistics. Regional mortality rates were obtained by aggregating the 443 municipalities in Norway into urban, rural, and intermediate municipalities.

Settings and subjects - Norway.

Results - In 1966-70 the age adjusted IHD/ SUD mortality in the age group 30-69 years was higher in urban than in rural areas; for men by $31 \%(95 \%$ CI $27 \%, 36 \%)$ and for women by $28 \%$ (95\% CI $19 \%, 36 \%)$. In 1986-89 the IHD/SUD mortality for men showed a reversed urban-rural gradient: it was $8 \%(95 \%$ CI $2 \%, 13 \%)$ higher in rural than in urban areas. The mortality rates for women were equal for both these aggregates. For men the results indicate that IHD/SUD mortality peaked first in urban municipalities and then, but at a lower level, in rural areas. For women there was a substantial decline in IHD/SUD mortality between 1966 and 1989, but an actual peak could not be demonstrated in any of the three aggregates during the period. The decline in IHD/SUD mortality among women was steepest in urban municipalities and least noticeable in rural municipalities, but the decline tapered of towards the end of the study period.

Conclusion - The results confirm a phaseshifted peak in IHD/SUD mortality, which began in towns and ended in rural areas, and provides clues to the main underlying factors in the IHD epidemic at the population level.
\end{abstract}

(f Epidemiol Community Health 1995;49:271-276)

The changes in mortality from ischaemic heart disease (IHD) in the western world during recent decades have not been regionally homogenous. Mortality time trend differences have been shown both between and within countries. ${ }^{1-3}$ Secular mortality changes have been generally similar in many regions, with a rapid increase in mortality which peaks then shows a substantial decline. The changes have been most dramatic for middle aged men. ${ }^{3}$ In Norway, substantial regional time trend differences in IHD mortality, including sudden death of unknown cause (IHD/SUD), have been documented in the period 1966-85. ${ }^{4}$ An increase in IHD/SUD mortality was seen in some rural areas, however, in contrast to the falling IHD/ SUD mortality evident at the national level. Observations from other western countries have indicated that the decline in IHD mortality began first in metropolitan and urban areas and later in rural districts. . $^{5-7}$

This study aimed to detect urban-rural differences in IHD mortality and in all cause mortality in Norway between 1966 and 1989. Three different municipal aggregates were considered: urban, rural, and intermediate municipalities.

\section{Methods}

THE NUMERATOR

This study was based on information recorded on death certificates for the age group 30-69 years, for the period 1966-89. The definition of IHD corresponded to the International Classification of Diseases, 7th revision (ICD7): $420+422 \cdot 1$ (1966-68), 8th revision (ICD8): 410-414 (1969-85), and 9th revision (ICD9): 410-414 (1986-89). The definition of sudden death of unknown cause (SUD), corresponded to ICD7: 795 2 (1966-68), ICD8: 795 (196985), and ICD9: 798.1 (1986-89). IHD and SUD were considered together and are referred to as IHD/SUD. These causes of death were combined because in Norway, in this age group, SUD shows the same epidemiological characteristics as IHD alone. ${ }^{8}$

\section{THE DENOMINATOR}

Population data for each of 443 demographic units, hereafter called municipalities, Norwegian: "kommuner") were supplied through the Norwegian Social Science Data Services. The mid-year population was estimated by averaging the population on 31 December for two consecutive years. The death certificates included information on residency, making it possible to calculate mortality rates based on the 443 municipalities.

CRITERIA FOR DEFINITION OF MUNICIPAL AGGREGATES

IHD/SUD mortality rates were calculated by aggregating the municipalities. The municipalities were grouped into urban, rural, and intermediate, primarily based on classification systems used by the Central Bureau of Statistics in Norway. ${ }^{9}$ Norwegian urban settlements are classified into three main categories: 
- (A) Main cities (each with a total population of $\geq 50000$ );

- (B) Large towns (population generally 10 000-50 000) and;

- (C) Smaller towns or urban settlements (population generally 5000-10 000).

In this study urban municipalities were defined as municipalities containing either of the first two types of urban settlement (main cities or large towns). Rural municipalities were al municipalities that did not include any urban settlement and were not located in the immediate neighbourhood of any urban settlement (centrality codes $\mathrm{OA}$ or $\mathrm{OB}$ according to the Central Bureau of Statistics). ${ }^{9}$ All other municipalities were classified as intermediate.

The location of urban, rural, and intermediate municipalities is shown in figure 1.

\section{STATISTICS}

Mortality rates were age standardised by fiveyear intervals by means of the direct method ${ }^{10}$ with the Norwegian population (men+ women) at 1 January 1980 as the standard population. The study period of 24 years was divided into four, five-year and one four-year (1986-89) period. The mortality rates were computed for each of these five consecutive intervals.

The regional mortality rates in the first fiveyear period were subtracted from the corresponding rates in the last four-year period and $95 \%$ confidence intervals $(95 \% \mathrm{CI})$ for these rate differences were computed, based on the assumption of a binomial model. ${ }^{10}$

The computer program used to calculate regional mortality rates was developed at the University of Trondheim, Department of Goegraphy. ${ }^{11} 12$

\section{Results}

MEN

In 1966-70, the urban municipalities had the highest IHD/SUD mortality by far (figure 2 ). The age adjusted IHD/SUD mortality for the age group 30-69 years was 31\% (95\% CI 27\%,

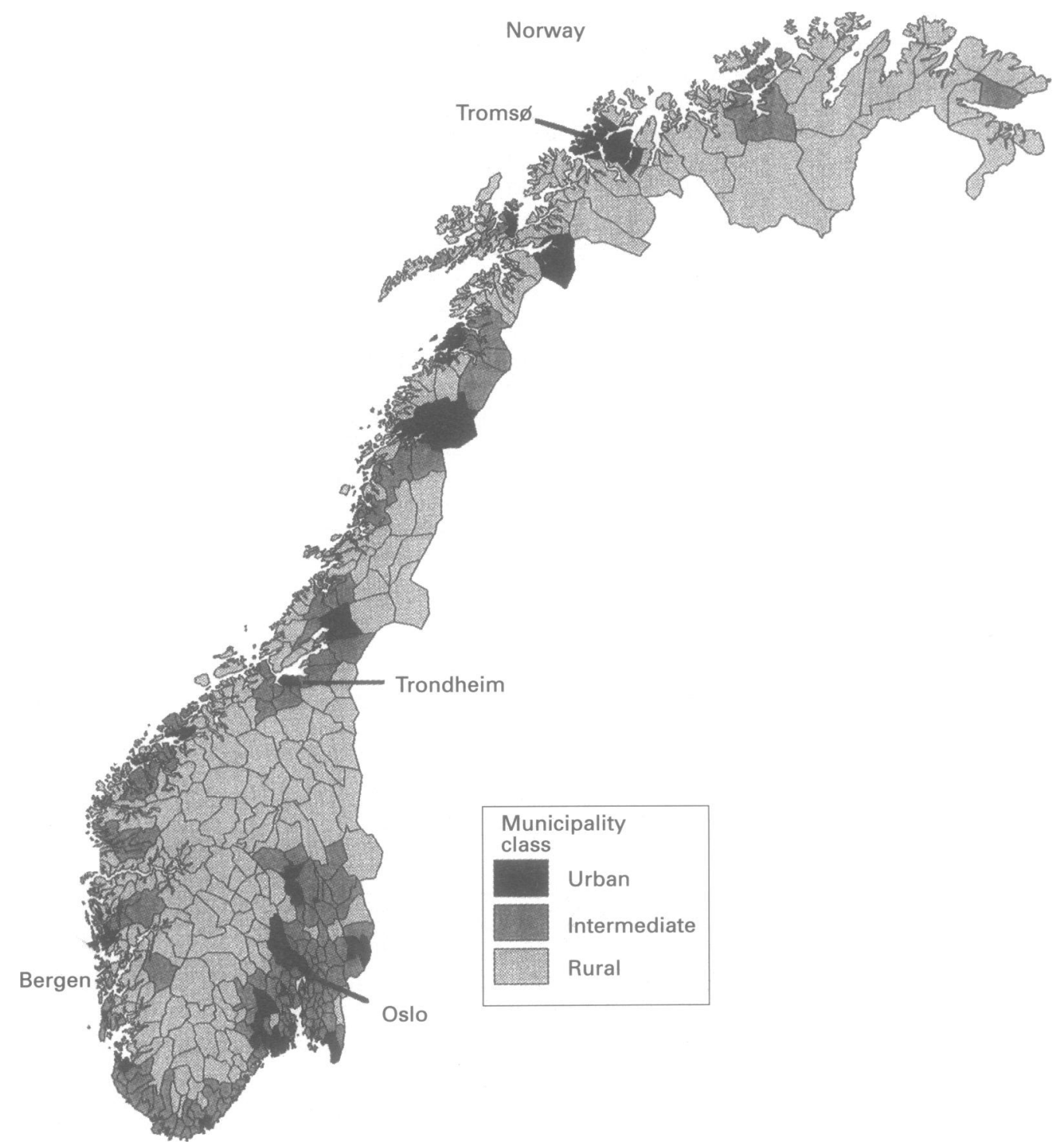

Figure 1 Location of urban, rural, and intermediate municipalities. Main cities are labelled. 

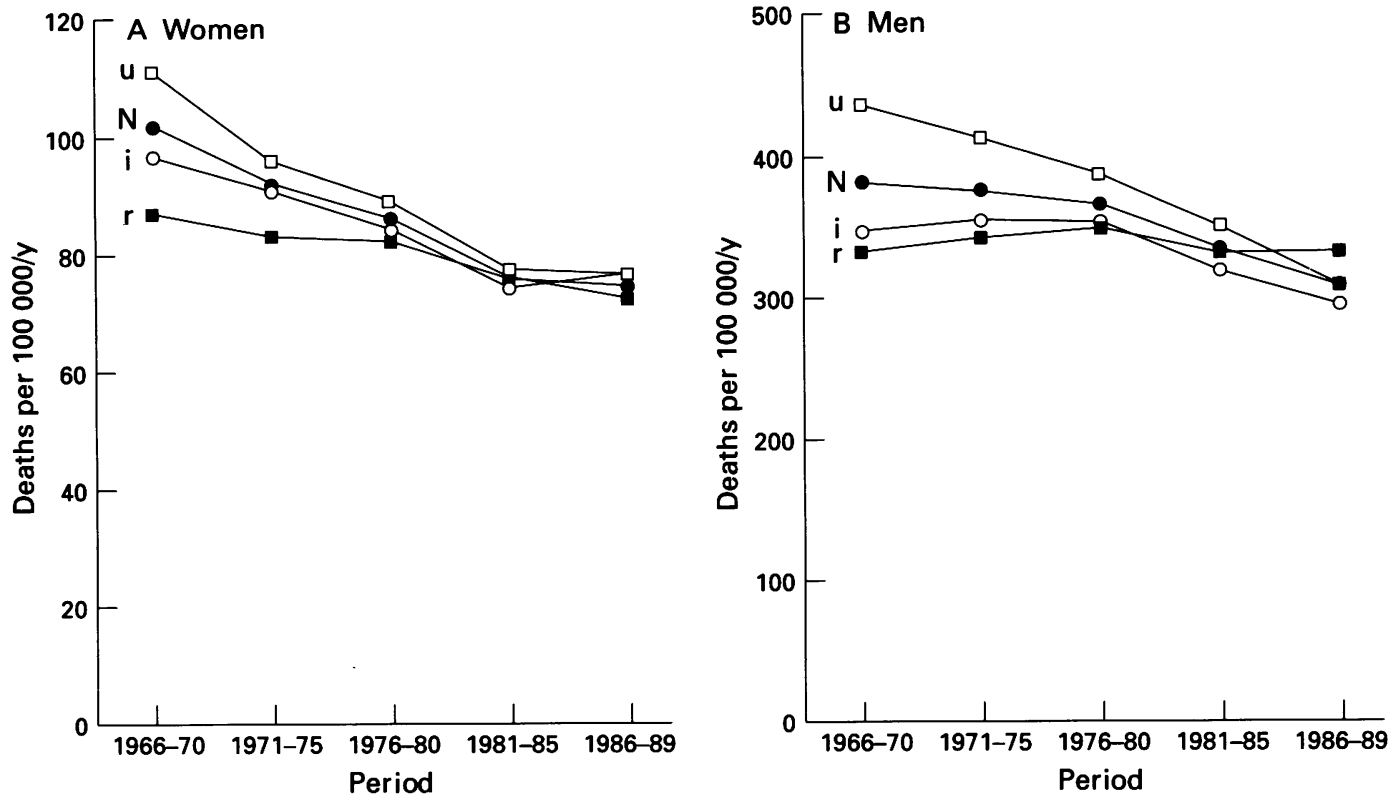

Figure 2 Mortality from ischaemic heart disease, including sudden death, cause unknown, among $(A)$ women and $(B)$ men in Norway, age 30-69 years, in urban, rural, and intermediate municipal aggregates. ( $N=$ Norway, $u=u r b a n, r=$ rural, $i=$ intermediate). Age adjusted mortality per 100 000/year.

$36 \%$ ) higher in urban than in rural municipalities. Mortality from all causes was also higher in urban areas $28 \%$ (95\% CI $25 \%$, $31 \%)$. By $1986-89$ the differences in IHD/ SUD mortality between the three municipal groupings had become smaller, but the gradient between urban and rural areas was then reversed, with an $8 \%(95 \%$ CI $2 \%, 13 \%)$ IHD/ SUD mortality excess in rural areas. The IHD/ SUD mortality time trends were thus different in the three municipal aggregates. In urban municipalities the age adjusted IHD/SUD mor-

Table 1 Men - mortality from ischaemic heart disease, including sudden, unexpected death (IHD/SUD) and all cause mortality in urban, rural, and intermediate municipals. Age specific mortality rates per $100000 /$ year (number of deaths in brackets)

\begin{tabular}{|c|c|c|c|c|c|c|}
\hline \multirow[t]{2}{*}{$\begin{array}{l}\text { Municipal } \\
\text { aggregate }\end{array}$} & \multicolumn{5}{|l|}{ Mortality } & \multirow{2}{*}{$\begin{array}{l}\text { Rate change from } \\
1966-70 \text { to } 1986-89 \\
\%(95 \% C I)\end{array}$} \\
\hline & $\begin{array}{l}1966-70 \\
\text { Rate }(n)\end{array}$ & $\begin{array}{l}1971-75 \\
\text { Rate (n) }\end{array}$ & $\begin{array}{l}1976-80 \\
\text { Rate }(n)\end{array}$ & $\begin{array}{l}1981-85 \\
\text { Rate }(n)\end{array}$ & $\begin{array}{l}1986-89 \\
\text { Rate }(n)\end{array}$ & \\
\hline \multicolumn{7}{|l|}{ Age 40-49y } \\
\hline $\begin{array}{l}\text { Urban } \\
\text { IHD/SUD } \\
\text { All causes }\end{array}$ & $\begin{array}{l}141(774) \\
405(2216)\end{array}$ & $\begin{array}{l}137(658) \\
395(1898)\end{array}$ & $\begin{array}{l}116(497) \\
368(1571)\end{array}$ & $\begin{array}{c}96(425) \\
332(1469)\end{array}$ & $\begin{array}{c}71(312) \\
318 \text { (1399) }\end{array}$ & $\begin{array}{l}-50(-59,-41) \\
-21(-27,-16)\end{array}$ \\
\hline $\begin{array}{c}\text { Intermediate } \\
\text { IHD/SUD } \\
\text { All causes }\end{array}$ & $\begin{array}{l}115(499) \\
351(1523)\end{array}$ & $\begin{array}{l}121(493) \\
340(1388)\end{array}$ & $\begin{array}{l}107(417) \\
330(1282)\end{array}$ & $\begin{aligned} 78 & (328) \\
278 & (1176)\end{aligned}$ & $\begin{array}{c}73(311) \\
279(1189)\end{array}$ & $\begin{array}{l}-37(-48,-25) \\
-21(-27,-14)\end{array}$ \\
\hline $\begin{array}{l}\text { Rural } \\
\text { IHD/SUD } \\
\text { All causes }\end{array}$ & $\begin{array}{l}121(315) \\
376(976)\end{array}$ & $\begin{array}{l}123(276) \\
363(816)\end{array}$ & $\begin{array}{l}127(255) \\
354(711)\end{array}$ & $\begin{array}{l}110(224) \\
360(735)\end{array}$ & $\begin{array}{r}86(166) \\
320(614)\end{array}$ & $\begin{array}{l}-29(-44,-13) \\
-15(-24,-6)\end{array}$ \\
\hline $\begin{array}{l}\text { Norway } \\
\text { IHD/SUD } \\
\text { All causes }\end{array}$ & $\begin{array}{l}128(1588) \\
380(4715)\end{array}$ & $\begin{array}{l}128(1427) \\
369(4102)\end{array}$ & $\begin{array}{l}115(1169) \\
351(3564)\end{array}$ & $\begin{array}{c}91(977) \\
316(3380)\end{array}$ & $\begin{array}{c}75(789) \\
303(3202)\end{array}$ & $\begin{array}{l}-41(-48,-35) \\
-20(-24,-16)\end{array}$ \\
\hline \multicolumn{7}{|l|}{ Age 50-59y } \\
\hline $\begin{array}{l}\text { Urban } \\
\text { IHD/SUD } \\
\text { All causes }\end{array}$ & $\begin{array}{r}455(2331) \\
1071(5491)\end{array}$ & $\begin{array}{r}447(2363) \\
1050(5548)\end{array}$ & $\begin{array}{r}430(2189) \\
1049(5335)\end{array}$ & $\begin{array}{r}386(1723) \\
1005(4486)\end{array}$ & $\begin{array}{l}332(1060) \\
924(2947)\end{array}$ & $\begin{array}{l}-27(-33,-21) \\
-14(-18,-10)\end{array}$ \\
\hline $\begin{array}{c}\text { Intermediate } \\
\text { IHD/SUD } \\
\text { All causes }\end{array}$ & $\begin{array}{l}360(1388) \\
854(3292)\end{array}$ & $\begin{array}{l}373(1548) \\
892(3699)\end{array}$ & $\begin{array}{l}391(1642) \\
907(3807)\end{array}$ & $\begin{array}{l}352(1377) \\
856(3353)\end{array}$ & $\begin{array}{l}304(902) \\
819(2432)\end{array}$ & $\begin{array}{l}-16(-23,-8) \\
-4(-9,1)\end{array}$ \\
\hline $\begin{array}{l}\text { Rural } \\
\text { IHD/SUD } \\
\text { All causes }\end{array}$ & $\begin{array}{l}350(916) \\
855(2234)\end{array}$ & $\begin{array}{l}385(989) \\
892(2291)\end{array}$ & $\begin{array}{l}377(909) \\
859(2073)\end{array}$ & $\begin{array}{l}368(782) \\
879(1868)\end{array}$ & $\begin{array}{l}335(515) \\
826(1269)\end{array}$ & $\begin{array}{l}-4(-15,6) \\
-3(-10,3)\end{array}$ \\
\hline $\begin{array}{l}\text { Norway } \\
\text { IHD/SUD } \\
\text { All causes }\end{array}$ & $\begin{array}{l}400(4635) \\
950(11017)\end{array}$ & $\begin{array}{l}408(4900) \\
961(11538)\end{array}$ & $\begin{array}{l}405(4740) \\
959(11215)\end{array}$ & $\begin{array}{l}369(3882) \\
924(9707)\end{array}$ & $\begin{array}{l}322(2477) \\
864(6648)\end{array}$ & $\begin{array}{l}-20(-24,-15) \\
-9(-12,-6)\end{array}$ \\
\hline $\begin{array}{l}\text { Age 60-69y } \\
\text { Urban }\end{array}$ & & & & & & \\
\hline $\begin{array}{l}\text { IHD/SUD } \\
\text { All causes }\end{array}$ & $\begin{array}{l}1221(4563) \\
2931(10952)\end{array}$ & $\begin{array}{l}1135(4556) \\
2728(10953)\end{array}$ & $\begin{array}{l}1080(4591) \\
2653(11282)\end{array}$ & $\begin{array}{c}984(4341) \\
2502(11038)\end{array}$ & $\begin{array}{r}901(3083) \\
2386(8165)\end{array}$ & $\begin{array}{l}-26(-30,-22) \\
-19(-21,-16)\end{array}$ \\
\hline $\begin{array}{c}\text { Intermediate } \\
\text { IHD/SUD } \\
\text { All causes }\end{array}$ & $\begin{array}{r}979(2763) \\
2359(6659)\end{array}$ & $\begin{array}{r}981(3042) \\
2291(7105)\end{array}$ & $\begin{array}{r}975(3288) \\
2266(7639)\end{array}$ & $\begin{array}{r}901(3265) \\
2233(8056)\end{array}$ & $\begin{array}{r}866(2555) \\
2224(6557)\end{array}$ & $\begin{array}{l}-13(-17,-6) \\
-6(-9,-2)\end{array}$ \\
\hline $\begin{array}{l}\text { Rural } \\
\text { IHD/SUD } \\
\text { All causes }\end{array}$ & $\begin{array}{r}918(1908) \\
2140(4446)\end{array}$ & $\begin{array}{r}922(2023) \\
2150(4718)\end{array}$ & $\begin{array}{r}969(2186) \\
2156(4866)\end{array}$ & $\begin{array}{r}919(2061) \\
2179(4885)\end{array}$ & $\begin{array}{r}981(1675) \\
2295(3918)\end{array}$ & $\begin{array}{l}7(0,14) \\
7(3,12)\end{array}$ \\
\hline $\begin{array}{l}\text { Norway } \\
\text { IHD/SUD } \\
\text { All causes }\end{array}$ & $\begin{array}{l}1069(9234) \\
2554(22057)\end{array}$ & $\begin{array}{l}1033(9621) \\
2446(22776)\end{array}$ & $\begin{array}{l}1019(10065) \\
2407(23787)\end{array}$ & $\begin{array}{c}941(3882) \\
2333(23979)\end{array}$ & $\begin{array}{r}905(7313) \\
2307(18640)\end{array}$ & $\begin{array}{l}-15(-18,-13) \\
-10(-11,-8)\end{array}$ \\
\hline
\end{tabular}


Table 2 Women - mortality from ischaemic heart disease, including sudden, unexpected death (IHD/SUD) and all cause mortality in urban, rural, and intermediate municipals. Age specific mortality rates per $100000 / y e a r$ (number of deaths in brackets)

\begin{tabular}{|c|c|c|c|c|c|c|}
\hline \multirow[t]{2}{*}{$\begin{array}{l}\text { Municipal } \\
\text { aggregate }\end{array}$} & \multicolumn{5}{|l|}{ Mortality } & \multirow{2}{*}{$\begin{array}{l}\text { Rate change from } \\
1966-70 \text { to } 1986-89 \\
\%(95 \% \mathrm{CI})\end{array}$} \\
\hline & $\begin{array}{l}1966-70 \\
\text { Rate (n) }\end{array}$ & $\begin{array}{l}1971-75 \\
\text { Rate (n) }\end{array}$ & $\begin{array}{l}1976-80 \\
\text { Rate }(n)\end{array}$ & $\begin{array}{l}1981-85 \\
\text { Rate (n) }\end{array}$ & $\begin{array}{l}1986-89 \\
\text { Rate }(n)\end{array}$ & \\
\hline \multicolumn{7}{|l|}{ Age 40-49y } \\
\hline $\begin{array}{l}\text { Urban } \\
\text { IHD/SUD } \\
\text { All causes }\end{array}$ & $\begin{array}{c}18(104) \\
209(1191)\end{array}$ & $\begin{array}{c}16(81) \\
196(970)\end{array}$ & $\begin{array}{c}16(71) \\
185(810)\end{array}$ & $\begin{array}{c}10(45) \\
175(778)\end{array}$ & $\begin{aligned} 8(36) \\
180(768)\end{aligned}$ & $\begin{array}{l}-56(-78,-29) \\
-14(-22,-6)\end{array}$ \\
\hline \multicolumn{7}{|l|}{ Intermediate } \\
\hline $\begin{array}{l}\text { IHD/SUD } \\
\text { All causes }\end{array}$ & $\begin{array}{r}12(48) \\
182(751)\end{array}$ & $\begin{array}{c}19(73) \\
189(735)\end{array}$ & $\begin{array}{c}16(60) \\
159(594)\end{array}$ & $\begin{array}{c}10(42) \\
162(660)\end{array}$ & $\begin{array}{c}13(52) \\
155(631)\end{array}$ & $\begin{array}{r}8(-31,51) \\
-15(-24,-5)\end{array}$ \\
\hline $\begin{array}{l}\text { Rural } \\
\text { IHD/SUD } \\
\text { All causes }\end{array}$ & $\begin{aligned} 18(43) \\
205(498)\end{aligned}$ & $\begin{array}{c}15(32) \\
172(357)\end{array}$ & $\begin{array}{c}12(22) \\
150(277)\end{array}$ & $\begin{aligned} 13 & (25) \\
138 & (259)\end{aligned}$ & $\begin{aligned} 12(21) \\
158(275)\end{aligned}$ & $\begin{array}{l}-32(-74,10) \\
-23(-36,-10)\end{array}$ \\
\hline $\begin{array}{l}\text { Norway } \\
\text { IHD/SUD } \\
\text { All causes }\end{array}$ & $\begin{array}{c}17(195) \\
199(2440)\end{array}$ & $\begin{array}{c}17(186) \\
189(2062)\end{array}$ & $\begin{array}{r}15(153) \\
169(1681)\end{array}$ & $\begin{array}{c}11(112) \\
163(1697)\end{array}$ & $\begin{array}{c}11(108) \\
166(1674)\end{array}$ & $\begin{array}{l}-35(-51,-13) \\
-17(-22,-11)\end{array}$ \\
\hline \multicolumn{7}{|l|}{ Age 50-59y } \\
\hline $\begin{array}{l}\text { Urban } \\
\text { IHD/SUD } \\
\text { All causes }\end{array}$ & $\begin{array}{c}79(449) \\
498(2833)\end{array}$ & $\begin{array}{c}76(443) \\
480(2785)\end{array}$ & $\begin{aligned} & 77(423) \\
& 494(2715)\end{aligned}$ & $\begin{array}{c}63(300) \\
446(2126)\end{array}$ & $\begin{array}{c}61(208) \\
471(1608)\end{array}$ & $\begin{array}{l}-23(-37,-9) \\
-5(-11,1)\end{array}$ \\
\hline $\begin{array}{c}\text { Intermediate } \\
\text { IHD/SUD } \\
\text { All causes }\end{array}$ & $\begin{array}{c}69(258) \\
455(1693)\end{array}$ & $\begin{aligned} 69 & (279) \\
435 & (1760)\end{aligned}$ & $\begin{aligned} 59 & (243) \\
412 & (1690)\end{aligned}$ & $\begin{aligned} & 63(241) \\
& 417(1598)\end{aligned}$ & $\begin{array}{c}52(152) \\
394(1146)\end{array}$ & $\begin{array}{l}-25(-42,-8) \\
-13(-20,-7)\end{array}$ \\
\hline $\begin{array}{l}\text { Rural } \\
\text { IHD/SUD } \\
\text { All causes } \\
\text { Norway }\end{array}$ & $\begin{array}{c}64(158) \\
445(1099)\end{array}$ & $\begin{array}{c}59(146) \\
408(1007)\end{array}$ & $\begin{array}{r}63(147) \\
403(936)\end{array}$ & $\begin{array}{r}65(131) \\
406(819)\end{array}$ & $\begin{array}{r}71(102) \\
425(614)\end{array}$ & $\begin{aligned} & 11(-16,37) \\
- & 5(-14,5)\end{aligned}$ \\
\hline $\begin{array}{l}\text { Norway } \\
\text { IHD/SUD } \\
\text { All causes }\end{array}$ & $\begin{array}{c}73(865) \\
474(5625)\end{array}$ & $\begin{array}{c}71(868) \\
451(5552)\end{array}$ & $\begin{array}{c}69(813) \\
448(5341)\end{array}$ & $\begin{array}{c}63(671) \\
428(4543)\end{array}$ & $\begin{array}{c}60(462) \\
434(3368)\end{array}$ & $\begin{array}{l}-19(-28,-8) \\
-8(-12,-4)\end{array}$ \\
\hline \multicolumn{7}{|l|}{ Age 60-69y } \\
\hline $\begin{array}{l}\text { Urban } \\
\text { IHD/SUD } \\
\text { All causes }\end{array}$ & $\begin{array}{r}373(1826) \\
1385(6774)\end{array}$ & $\begin{array}{r}314(1595) \\
1228(6242)\end{array}$ & $\begin{array}{r}289(1510) \\
1197(6257)\end{array}$ & $\begin{array}{r}255(1364) \\
1116(5972)\end{array}$ & $\begin{array}{r}263(1077) \\
1131(4626)\end{array}$ & $\begin{array}{l}-29(-36,-23) \\
-18(-22,-15)\end{array}$ \\
\hline $\begin{array}{c}\text { Intermediate } \\
\text { IHD/SUD } \\
\text { All causes }\end{array}$ & $\begin{array}{c}325(961) \\
1324(3908)\end{array}$ & $\begin{array}{c}291(940) \\
1180(3809)\end{array}$ & $\begin{array}{c}285(999) \\
1095(3838)\end{array}$ & $\begin{array}{c}240(917) \\
1006(3841)\end{array}$ & $\begin{array}{c}244(757) \\
1026(3188)\end{array}$ & $\begin{array}{l}-25(-33,-17) \\
-23(-27,-18)\end{array}$ \\
\hline $\begin{array}{l}\text { Rural } \\
\text { IHD/SUD } \\
\text { All causes }\end{array}$ & $\begin{array}{c}288(589) \\
1239(2536)\end{array}$ & $\begin{array}{c}278(606) \\
1136(2473)\end{array}$ & $\begin{array}{c}273(625) \\
1061(2430)\end{array}$ & $\begin{array}{l}246(573) \\
982(2288)\end{array}$ & $\begin{array}{l}226(401) \\
946(1681)\end{array}$ & $\begin{array}{l}-22(-33,-10) \\
-24(-29,-18)\end{array}$ \\
\hline $\begin{array}{l}\text { Norway } \\
\text { IHD/SUD } \\
\text { All causes }\end{array}$ & $\begin{array}{c}345(3376) \\
1337(13218)\end{array}$ & $\begin{array}{c}300(3141) \\
1194(12524)\end{array}$ & $\begin{array}{c}285(3134) \\
1136(12525)\end{array}$ & $\begin{array}{c}248(2854) \\
1053(12101)\end{array}$ & $\begin{array}{r}250(2235) \\
1058(9495)\end{array}$ & $\begin{array}{l}-28(-32,-23) \\
-21(-23,-19)\end{array}$ \\
\hline
\end{tabular}

tality rates for men declined steadily throughout the whole study period. In intermediate municipalities IHD/SUD mortality increased slightly from $1966-70$ to $1971-75$, but thereafter decreased by $17 \%$ (95\% CI $-13 \%$, $-21 \%$ ) to $1986-89$. In rural municipalities mortality increased by $5 \%$ (95\% CI $0 \%, 10 \%)$ between 1966-70 and 1976-80 but declined by $5 \%(95 \%$ CI $-1 \%,-10 \%)$ between 1976-80 and 1986-89.

When deaths were grouped according to ages $40-49,50-59$, and 60-69 years, the relative decline in IHD/SUD mortality, as well as in all cause mortality, was most noticeable in the youngest group (table 1). Urban-rural mortality time trend differences were evident in all three age groups, indicating early mortality peaks in urban compared with rural municipalities. This applied to both IHD/SUD and to all cause mortality. Reversal in the direction of the urban-rural difference in IHD/SUD mortality from 1966-70 to 1986-89 was formally observed in all three 10-year age groups, although in the 50-59 years group, urban and rural mortality rates were virtually identical in the last period.

For Norway as a whole, the calendar period in which the IHD/SUD mortality rate was maximal coincided with the maximal all cause mortality rate in all three age groups.
WOMEN

Declines in the age adjusted IHD/SUD mortality rates for women aged 30-69 years were apparent from 1966-70 in all three municipal aggregates. The decline was most noticeable in the urban area (figure 2) and the difference between the urban and the two more rural municipal aggregates considerably reduced during the study. Only minor mortality differences persisted between the three municipal aggregates by $1986-89$. The reduction in IHD/ SUD mortality was accompanied by a reduction in all cause mortality. From 1981-85 to $1986-89$ the IHD/SUD mortality changed very little.

When split into 10-year age groups, there were few deaths in the 40-49 and 50-59 year groups, which made the data from these statistically imprecise (table 2). In the 60-69 year group, IHD/SUD mortality increased slightly from $1981-85$ to $1986-89$ in urban areas and in intermediate municipalities.

\section{Discussion}

This study has shown different IHD/SUD mortality time trends in urban regions and in more remote areas of Norway. For men we have detected a reversal in the urban-rural IHD mortality differences over the period 1966-89. 
Vital statistics should always be considered with caution. Differences or changes in diagnostic habits and practice can introduce biases and disturb the validity of observed temporal or spatial differences. Random fluctuations are also a problem in small populations and/or in situations where the numbers or deaths are low. Aside from these artefacts, differences in regional diagnosis specific mortality must be explained by differences in incidence of the disease and/or differences in case fatality rates.

In view of the homogeneity of the Norwegian medical system, it seems unlikely that systematic diagnostic biases could invalidate the substantial regional differences observed. All the coding of death certificates is done at the Central Bureau of Statistics in Oslo, and identical coding practices are therefore applied to all regions.

An important indication that the regional IHD/SUD mortality differences observed in this study are not artefacts resulting from diagnostic biases is that the all cause mortality generally mirrors the IHD/SUD mortality, both with regard to time trends within any municipal aggregate and differences between the municipal aggregates.

The possible impact of case fatality rate reduction on the IHD/SUD mortality cannot be assessed in the present study. These effects remain a highly controversial issue. ${ }^{13-14}$ Results from Tromsø, an urban municipality in northern Norway, indicate that one year survival after the first infarction did not improve noticeably from 1975 to 1985 (Kaare Bönaa, personal communication). Even though a beneficial effect of improved medical care may have contributed to the fall in mortality in the urban areas, it should be noted that the increase in IHD/SUD mortality in rural districts occurred during a period when medical care certainly improved.

We find it reasonable to assume that the mortality time trend differentials reflect true regional incidence differences, implying that the explanations should be sought in primary aetiological factors and not in inequalities in medical care.

MEN

The results show a remarkable reversal of the IHD/SUD mortality difference between urban and rural municipalities, even though these mortality rates have become more homogenous. The peak in age adjusted IHD/SUD mortality for the age group 30-69 years appeared first in urban municipalities, then in intermediate municipalities, and lastly in rural areas. The peak level for IHD/SUD mortality in men was substantially lower in the two more rural aggregates than in the urban municipalities. The findings are in line with observations in other countries, which show lagged IHD mortality changes in remote or rural areas ${ }^{5-7}$ compared with metropolitan or central regions. This study not only indicates different starting points for the decline in IHD mortality in urban and rural areas, but also that urban and rural IHD mortality time trends can show opposite directions in a given time window. In view of the time trends over the last part of the study period, the present IHD/ SUD mortality excess in rural areas may become even greater.

\section{WOMEN}

IHD/SUD mortality declined from $1966-70$ to 1986-89 in all three municipal aggregates. The decline was steepest in the urban regions and least pronounced for rural municipalities, resulting in increased homogeneity of mortality rates.

A longer historical observation period would have been necessary to demonstrate possible regional differences in IHD mortality culmination times for women.

The mortality results for women indicate that the urban-rural differentials are the same, in principle, for women as for men, but that the IHD mortality peak may have occurred earlier for women than for men. In the United States, differences in the onset of the decline in IHD mortality among women have been shown to have many of the same geographic and socioeconomic characteristics as those for men. That is, an earlier decline in urban areas and in areas with a high proportion of high income and of white collar workers. ${ }^{15}$

The rate of decline in IHD/SUD mortality for women seemed to stagnate during the last part of the study period. In urban municipalities as well as in intermediate municipalities, there was a slight mortality increase in the age group 60-69 years between 1981-85 and 1986-89. For men we have shown a tendency for the change in mortality to occur first in urban areas. If this also applies to women, it is possible that we are at a starting point of an actual IHD/ SUD mortality increase for women, which will later become apparent at the national level. One factor of possible aetiologic importance is increased tobacco smoking among Norwegian women. The prevalence of daily smokers among 55-64 year old women increased from $19 \%$ in 1973 to $32 \%$ in 1990 (National Council on Tobacco and Health, personal communication). The Norwegian smoking data also indicate different time trends for smoking in women living in counties with urban dominance (Oslo, Akershus) compared with countries with rural dominance (Møre og Romsdal and Trøndelag). The age adjusted incidence rate for lung cancer among Norwegian women increased $61 \%$ from 1982 to $1991,{ }^{16}$ illustrating the current trend of another smoking related disease. It will be important to monitor closely the IHD mortality in women.

THE DYNAMICS OF THE IHD EPIDEMIC

Mortality time trend differences between nations or population groups might be described simply as differences in the chronological time at which a decline began. It should be realised, however, that the mortality decline is often preceded by a phase of rapid increase in IHD mortality. This phenomenon is an important aspect of the IHD epidemic. 
The mortality findings in the present study are consistent with a lagged mortality change in rural areas. The regional mortality curves look basically similar, but out of phase with one another. Within a nation, regional mortality findings can be quite confusing - some regions may have increasing IHD mortality and at the same time as mortality declines in others. This is illustrated in the present study by comparing IHD mortality changes in urban and in rural municipalities during the period 1966-1980: there was rapid decrease in the urban areas and a continued slight increase in rural ones.

\section{LIFE STYLE DIFFUSION}

IHD is strongly related to life style. The urbanrural differences could be explained by a process in which life style changes spread from central or metropolitan regions to the periphery. These changes can be unfavourable as well as beneficial to health. There are indications that unfavourable life style factors associated with newly gained prosperity, ${ }^{17}$ first hit the urban areas, but also that subsequent knowledge of the harmful effects of elements of this new life style first make their behavioural impact in the cities. As a consequence, IHD mortality would be expected to culiminate first in urban regions and last in the most remote regions.

This proposed life style diffusion is in line with diffusion phenomena involving cultural and social innovations in general. These hierarchical processes were first formally described by the Swedish geographer Hägerstrand, in $1958 .^{18}$ The processes are analogous to the downwards or cascade diffusion of life style through socioeconomic groups. ${ }^{19}$ Examples of harmful life style elements of a aetiological importance for IHD are a high amount of saturated fat in the diet, tobacco smoking, and low physical activity.

Several studies on dietary habits have been performed in different regions of Norway since the 1930s. None of these have explicitly analysed time trend differences between urban and rural regions. Data from more recent dietary surveys may give clues to the proposed life style diffusion process described above. Johansson reviewed results from Norwegian dietary studies performed in 1979,1985 , and $1988 .{ }^{20}$ From 1979 to 1988 consumption of food rich on saturated fat was substantially more reduced in high income families than in low income families, and more reduced in urban areas than in rural districts. In 1988 the consumption of whole milk and of butter or margarine on bread was higher in the rural districts than in urban areas. This contrasts with observations from the 1930s and 1950s when the diet in the rural districts contained less fat than that in the cities. ${ }^{21}$ The urban-rural contrasts were consistent for men and women.

\section{IMPLICATIONS FOR PREVENTIVE STRATEGIES}

The urban-rural differences in IHD/SUD mortality time trends should be taken into account in the preventive health care planning for two main reasons: firstly, the effect of continuing community based or national intervention programmes on mortality could be profoundly biased by these underlying secular tendencies. One can reach apparently different conclusions about the effect on mortality, depending on whether or not the population under study belongs to the trend leading part (that is, the more favourable time trends in the cities). The hypothetical effect of successful intervention efforts in rural regions with "lagged" IHD mortality changes could be a IHD mortality peak at a lower level than would otherwise have occurred, rather than an immediate start of mortality decline. Thus, community intervention programmes could be accompanied by continued mortality increase for some years after the start of such programmes. This phenomenon has recently been demonstrated in one Norwegian county. ${ }^{22}$ Secondly, future strategies focussing on dietary or life style change should possibly be focussed differently in urban regions than in the rural districts, as the main underlying forces of behavioural change may have different directions.

This study has been financially supported by The Norwegian Research Council.

1 Thom TJ, Epstein FH, Feldman JJ, Leaverton PE. Trends in total mortality and mortality from heart disease in 26 countries from 1950 to 1978. Int 7 Epidemiol 1985;14: $510-20$

2 Kimm SY, Ornstein SM, Delong ER, Grufferman S. Secular trends in ischemic heart disease mortality: regional variation. Circulation 1983;68:3-8.

3 World Health Organization World Health Statistics Annual 1988. Geneva: WHO, 1988.

4 Krüger $\emptyset$, Westin S, Nymoen EH. Ischaemic heart disease among men in Norway during the period 1966-1985: two counties with different mortality time trends. 7 Int Med 1990;228:483-91.

5 Stallones $\mathrm{R}$. The rise and fall of ischemic heart disease. $S c i$ Am 1980;243:53-9.

6 Wing S, Hayes G, John E, Knowles M, Riggan W, Tyroler HA. Geographic variation in the onset of decline of ischHA. Geographic variation in the onset of decline of ischemic heart disease mortality in

7 Mackenbach JP, Looman CW, Kunst AE. Geographic variation in the onset of decline of ischemic heart disease mortality in The Netherlands, 1969-1984. Am f Public Health 1989;79:1621-7.

8 Tverdal Aa. $A$ mortality follow-up of persons invited to a cardiovascular disease study in five areas in Norway. Oslo: National Health Screening Service, 1989. (Thesis)

9 Central Bureau of Statistics. Standard for classification of municipalities. Oslo: Central Bureau of Statistics, 1985.

10 Armitage P, Berry G. Statistical methods in medical research. Oxford: Blackwell Scientific Publications, 1987:400-3.

11 Aase A. Regionalizing mortality data: ischaemic heart disease in Norway. Soc Sci Med 1989;29:907-11.

12 Nymoen EH. GEMINO - geographical mortality information system for Norway. (Report no 84) Trondheim: Department system for Norway. (Report no 84) Trondheim: Depa

13 Goldman L, Cook EF. The decline in ischemic heart disease mortality rates. An analysis of the comparative effects of medical interventions and changes in lifestyle. Ann Intern Med 1984;101:825-36.

14 Pitt B. Therapy for myocardial infarction: an effect on trends in coronary heart disease mortality. Int $\mathcal{f}$ Epidemiol 1989 18(suppl 1):223-7.

15 Wing S, Barnett E, Casper M, Tyroler HA. Geographic and socioeconomic variation in the onset of decline of coronary heart disease mortality in white women. Am $\mathcal{F}$ Public 1992 82:204-9.

16 Cancer Registry of Norway. Incidence of cancer in Norway 1991. Oslo: Cancer Registry of Norway, 1993:8.

17 Rose G, Shipley M. Effects of coronary risk reduction on the patterns of mortality. Lancet 1990;335:275-7.

18 Hägerstrand T. Innovation diffusion as a spatial process. Chicago: University of Chicago Press, 1968.

19 Marmot M, McDowall ME. Mortality decline and widening social inequalities. Lancet 1986;ii:274-6.

20 Johansson L, Dahle HK. The Norwegian diet is changing. Tidsskr Nor Lageforen 1990;110:29-31 (in Norwegian).

21 Johansson L. Who chooses a lean diet? Naringsforskning 1990;34:97-101 (in Norwegian).

22 Krüger $\emptyset$. Risk factor changes and mortality changes: a regional perspective on ischaemic heart disease in Norway 1966-85. Soc Sci Med 1991;33:423-8. 